\title{
Charles Trevelyan, John Mitchel and the historiography of the Great Famine
}

Charles Trevelyan, John Mitchel et l'historiographie de la Grande Famine

\section{Christophe Gillissen}

\section{(2) OpenEdition}

1 Journals

Electronic version

URL: https://journals.openedition.org/rfcb/281

DOI: $10.4000 / \mathrm{rfcb} .281$

ISSN: 2429-4373

Publisher

CRECIB - Centre de recherche et d'études en civilisation britannique

\section{Printed version}

Date of publication: 1 September 2014

Number of pages: $195-212$

ISSN: 0248-9015

\section{Electronic reference}

Christophe Gillissen, "Charles Trevelyan, John Mitchel and the historiography of the Great Famine", Revue Française de Civilisation Britannique [Online], XIX-2 | 2014, Online since 01 May 2015, connection on 21 September 2021. URL: http://journals.openedition.org/rfcb/281 ; DOI: https://doi.org/10.4000/ rfcb.281

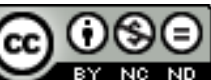

Revue française de civilisation britannique est mis à disposition selon les termes de la licence Creative Commons Attribution - Pas d'Utilisation Commerciale - Pas de Modification 4.0 International. 


\title{
Charles Trevelyan, John Mitchel and the historiography of the Great Famine
}

\author{
Christophe GILLISSEN \\ Université de Caen-Basse Normandie
}

The Great Irish Famine produced a staggering amount of paperwork: innumerable letters, reports, articles, tables of statistics and books were written to cover the catastrophe. Yet two distinct voices emerge from the hubbub: those of Charles Trevelyan, a British civil servant who supervised relief operations during the Famine, and John Mitchel, an Irish nationalist who blamed London for the many Famine-related deaths. ${ }^{1}$ They may be considered as representative to some extent, albeit in an extreme form, of two dominant trends within its historiography as far as London's role during the Famine is concerned. Indeed, revisionists generally downplay Britain's responsibility, stressing the fact that the Famine was a natural disaster of unprecedented scale and that the British Government deployed extraordinary means to deal with it, though admittedly with limited success. Nationalists and post-revisionists on the other hand consider that London failed to live up to its duty to protect the Irish, whom it perceived as second-class subjects of the United Kingdom, and who thus could not avail themselves of the full resources of the Exchequer of the most developed nation of its time.

In order to better understand the issues, the article will first look at Trevelyan and Mitchel's interpretations of the Great Famine, before turning to later developments in the writing of its history: the first scholarly works on the subject, the emergence of revisionism, Irish reluctance to come to terms with the Famine, and the outpouring of new work since its $150^{\text {th }}$ anniversary.

\section{Charles Trevelyan}

Charles Edward Trevelyan was Assistant Secretary to the Treasury from 1840 to 1859 - in other words, its highest-ranking civil servant, working under the direct authority of the Chancellor of the Exchequer. Trevelyan's influence over relief operations in Ireland must not be underestimated, especially as the various departments involved - the Board of Works, the Poor Law Commissioners, and the Commissariat - all depended more or less directly on the Treasury. ${ }^{2}$ Trevelyan's

\footnotetext{
${ }^{1}$ See Laurent COLANTONIO, 'La Grande Famine en Irlande (1846-1851) : objet d'histoire, enjeu de mémoire', Revue historique, No. 664, October 2007, pp. 899-925. Available at: $<$ http://www.cairn.info/revue-historique-2007-4-page-899.htm>.

${ }^{2}$ Robert B. McDOWELL, 'Administration and the public services, $1800-70$ ', pp. 538-561 in William E. VAUGHAN (ed.), A New History of Ireland, Vol. V: Ireland under the Union (1): 1801-70, Oxford: Clarendon Press, 1989, p. 559.
} 
control over the administration of relief became almost total after the Conservative Prime Minister, Robert Peel, resigned in June 1846 and a Whig government was formed under the leadership of Lord John Russell. Indeed, whereas Peel - widely recognised as the best statesman of his generation - had first-hand experience of Ireland and did not hesitate to take quick and decisive measures, Russell did not have comparable leadership skills and was constrained by an uncertain majority in Parliament. A weak government gives more scope to active senior civil servants, and Trevelyan was exceptional in terms both of his capacity to work long hours and of his self-assurance. In addition, as a 'partisan Whig' he was ideologically closer to his political masters after June 1846, notably in the case of the Chancellor, Charles Wood. ${ }^{3}$ This resulted in 'a dominant set of views [which] formed the basis from which the cabinet approached the problem of Irish distress'. ${ }^{4}$ Those views, which were shaped in particular by providentialism and laissez-faire, led to the conclusion that the best way to deal with the famine was for the Government to limit itself to providing employment on public works while distribution of food should be left to private charities, with the possible exception of remote areas; as to the cost of relief, it was to be borne by Ireland.

In January 1848, Trevelyan wrote an anonymous article, published in the Edinburgh Review. ${ }^{5}$ Considering that the crisis in Ireland was over, he delivered a robust defence of British relief policy: he stressed the scale of the challenge as well as the difficulty of implementing effective measures, emphasised the generosity of British donors, and concluded on the success of Government measures. On the whole it is a remarkable text, covering much ground and marshalling numerous arguments; it certainly testifies to Trevelyan's talents as an administrator. Yet it expresses little sensitivity to the plight of the hungry who are almost entirely absent from its pages, the author's main concern being to demonstrate his adherence to the economic orthodoxy of the day:

First, it has been proved to demonstration, that local distress cannot be relieved out of national funds without great abuses and evils, tending, by a direct and rapid process, to an entire disorganisation of society. This is, in effect, to expose the common stock to a general scramble. All are interested in getting as much as they can. It is nobody's concern to put a check on the expenditure. If the poor man prefers idling on relief works or being rationed with his wife and children, to hard labour; if the farmer discharges his labourers and makes the state of things a plea for not paying rates or rent; if the landed proprietor joins in the common cry, hoping to obtain some present advantage, and trusting to the chance of escaping future repayments, it is not the men, but the system, which is in fault. Ireland is not the only country which would have been thrown off its balance by the attraction of "public money" à discretion. This false principle

\footnotetext{
${ }^{3}$ Peter GRAY, Famine, Land and Politics: British Government and Irish Society, 1843-50, Dublin: Irish Academic Press, 1999, pp. 24-26.

${ }^{4}$ Gearóid Ó TUATHAIGH, Ireland Before the Famine, 1798-1848 [1972], Dublin: Gill \& Macmillan, $2^{\text {nd }}$ ed. 1990 , p. 189.

5 'The Irish Crisis', Edinburgh Review, Vol. 87, no. 175, January 1848, pp. 229-320.
} 
eats like a canker into the moral health and physical prosperity of the people. All classes "make a poor mouth," as it is expressively called in Ireland. They conceal their advantages, exaggerate their difficulties, and relax their exertions. The cotter does not sow his holding, the proprietor does not employ his poor in improving his estate, because by doing so they would disentitle themselves to their "share of the relief." 6

While an assistant secretary to the Treasury must ensure the proper use of public money, such a passage written as hundreds of thousands of Irishmen were close to death reflects a singular indifference to the sufferings of fellow citizens. Trevelyan firmly believed the Government had been right to refuse to interfere in the workings of the food trade, quoting the Lord Lieutenant to the effect that the Irish market was 'freer, cheaper, and better supplied, than that of any country in Europe where distress prevailed, and where those measures of interference and restriction had been unwisely adopted which were successfully resisted here'. ${ }^{7} \mathrm{He}$ also presented the winding down of public works in 1847 as part of a successful strategy, allowing Irish farmers to prepare the next harvest:

the Government, seeing that the time suited for agricultural operations was rapidly passing away, and that the utmost exertions made on the spot had failed in keeping the numbers in check, took the matter into its own hands, and directed that on the 20th March, 20 per cent of the persons employed should be struck off the lists; after which, successive reductions were ordered, proportioned to the progress made in bringing the new system of relief into operation in each district. These orders were obeyed, and the crisis passed without any disturbance of the public peace or any perceptible aggravation of the distress. The necessary labour was returned to agriculture, and the foundation was laid of the late abundant harvest in Ireland, by which the downward progress of that country has been mercifully stayed, and new strength and spirits have been given for working out her regeneration. ${ }^{8}$

All that was part of an extremely optimistic assessment of the situation, and an Englishman reading it at the time would obviously have concluded that the Famine in Ireland was over and that he could be proud of his country's achievement. He would have felt that the man who had supervised the administration of those relief operations was worthy of a knighthood for his services, which Trevelyan was duly awarded a few weeks later, on 27 April 1848.

The Edinburgh Review, a Whig organ, published several other pieces on Ireland and the famine by like-minded thinkers, such as Nassau William Senior, one

\footnotetext{
${ }^{6}$ Charles Edward TREVELYAN, The Irish Crisis, London: Longman, Brown, Green \& Longmans, 1848, pp. 183-184 (the article from the Edinburgh Review was published later in the year in book form, under the author's name).

${ }^{7}$ Ibid., p. 74.

${ }^{8}$ Ibid., p. 65.
} 
of the most influential intellectuals of his time. ${ }^{9}$ The gist was that public relief was not only useless but counterproductive, since it would encourage the Irish landlords and tenants alike - to remain idle instead of taking action to improve their lot. Any attempt to interfere in the workings of the market, be it by banning exports of food or by using public money to feed the hungry, would stifle private enterprise and wreak havoc with the country's economy. More generally, there was the idea that Irish society and agriculture were fundamentally unsustainable and required a major overhaul if they were not to remain a permanent burden on the Exchequer. They had proved impossible to reform in previous decades despite the best efforts of the British Government, but the Famine provided a unique opportunity to reshape them. Even though that entailed large-scale evictions and emigration, it was the only way to bring about any lasting improvement. As Trevelyan explained in a letter to Lord Monteagle (Thomas Spring Rice), an Irish landlord and Whig politician, in October 1846:

I think I see a bright light shining in the distance through the dark cloud which at present hangs over Ireland. A remedy has already been applied to that portion of the maladies of Ireland which was traceable to political causes, and the morbid habits which still to a certain extent survive are gradually giving way to more healthy action. The deep and inveterate root of social evil remains, and I hope I am not guilty of irreverence in thinking that, this being altogether beyond the power of man, the cure has been applied by the direct stroke of an all-wise Providence in a manner as unexpected and unthought as it is likely to be effectual. ${ }^{10}$

\section{John Mitchel}

On the other side of the Irish Sea, such an attitude was seen by some as part of a deliberate attempt to cull the Irish population. In 1848 Charles Gavan Duffy, the founder of The Nation, presented the Famine as 'a fearful murder committed on the mass of the people. ${ }^{11}$ John Mitchel, who wrote for The Nation, eventually broke with the more moderate element of the Young Ireland movement in 1847 to found a revolutionary paper, the United Irishman. His inflamed articles against British rule in Ireland resulted in his conviction for treason in 1848, and he was transported to Bermuda before being transferred to Van Diemen's Land, a penal colony off the Australian coast. In 1853 he managed to escape to the United States, where he published a book that had long-lasting influence on nationalist interpretations of the Famine: The Last Conquest of Ireland (Perhaps), which was originally serialised in an American newspaper in 1858, before being published in book form in 1860. It is a history of Ireland during the 1840s, or, as Mitchel puts it,

${ }^{9}$ See Nassau William SENIOR, Journals, Conversations, and Essays relating to Ireland, 2 vol., London: Longmans, Green and $\mathrm{C}^{\circ}, 1868$.

109 October 1846, quoted in Noel KISSANE, The Irish Famine: a documentary history, Dublin: National Library of Ireland, 1995, p. 51.

${ }_{11}$ Robert DUDLEY EDWARDS and Thomas Desmond WILLIAMS (eds), The Great Famine: Studies in Irish History, 1845-53 [1956], ed. Cormac Ó GRÁDA, Dublin: Lilliput Press, 1994, p. vii. 
the story of an ancient nation stricken down by a war more ruthless and sanguinary than any seven years' war, or thirty years' war, that Europe ever saw. No sack of Madgeburg, or ravage of the Palatinate, ever approached in horror and desolation to the slaughters done in Ireland by mere official red tape and stationery, and the principles of political economy. ${ }^{12}$

From his point of view, London was responsible for the death of 1.5 million people. One of his main arguments was that Ireland produced more than enough to feed the entire population of Ireland, and that a ban on exports of food - similar to those introduced in other European countries at the time - would have sufficed to prevent the Famine. His indignation permeates almost every page of his book, notably the conclusion which contains a famous line denouncing providentialist accounts of the Famine:

Now, that million and a half of men, women, and children, were carefully, prudently, and peacefully slain by the English government. They died of hunger in the midst of abundance, which their own hands created; and it is quite immaterial to distinguish those who perish in the agonies of famine itself from those who died of typhus fever, which in Ireland is always caused by famine.

Further, I have called it an artificial famine: that is to say, it was a famine which desolated a rich and fertile island, that produced every year abundance and superabundance to sustain all her people and many more. The English, indeed, call that famine a "dispensation of Providence;" and ascribe it entirely to the blight of the potatoes. But potatoes failed in like manner all over Europe; yet there was no famine save in Ireland. The British account of the matter, then, is first, a fraud - second, a blasphemy. The Almighty, indeed, sent the potato blight, but the English created the famine. ${ }^{13}$

In following decades, Mitchel's interpretation gained ground among Irish nationalists. Arthur Griffith, the founder of Sinn Féin, a radical nationalist party of the early $20^{\text {th }}$ century, viewed the Great Famine as an attempt by the British to exterminate the Celts of Ireland, and even as late as in 1952 this nationalist brand of history was pursued by P. S. O'Hegarty in his history of the Union: 'In the known facts of the business there is justification for the view that the Government policy under which over a million died, and over a million emigrated in five years, was a deliberate policy of extermination'. ${ }^{14}$ Among his arguments, the issue of food exports looms large; he quotes for instance a letter from the parish priest of Kells published in The Nation on 25 October 1845:

12 John MITCHEL, The Last Conquest of Ireland (Perhaps) [1861], ed. Patrick MAUME, Dublin: UCD Press, 2005, p. 218.

${ }^{13}$ Ibid., p. 219.

${ }^{14}$ Patrick Sarsfield O'HEGARTY, A History of Ireland under the Union, 1801-1922, London: Methuen, 1952, p. 328. 
With starvation at our doors, grimly staring us, vessels laden with our sole hopes of existence, our provisions, are hourly wafted from our every port. From one milling establishment I have last night seen not less than fifty dray loads of meal moving on to Drogheda, thence to go to feed the foreigner, leaving starvation and death the sure and certain fate of the toil and sweat that raised this food. ${ }^{15}$

More recently, Tim Pat Coogan, a renowned journalist and best-selling writer on Irish history, has developed this reading of the Famine in connection with the United Nations' definition of genocide in its 1948 Convention. His line is that 'Whig policy was directed at getting the peasants off the land, and if it took mass death to achieve that objective, so be it'. ${ }^{16}$ Among the evidence to justify that view are various statements and letters by British policy-makers, and in particular two anonymous letters written by Trevelyan to the Morning Chronicle in October 1843. He had just sojourned in Ireland for six weeks prior to Daniel O'Connell's mass political rally against the Union in Clontarf - which was banned at the eleventh hour - and he came to believe that a mass uprising was imminent. He was convinced that military preparations were under way all over the island and he accused the Roman Catholic clergy of manipulating the people to that end. It may be that the Irish were only too happy to pull the leg of the intense, humourless Englishman: standing out from the crowd, making all-too-obvious inquiries, he would have been an irresistible target for 'the favourite Irish sport of "codding" a stranger., 17

But the episode reveals another trait of the Assistant Secretary's character: on his return from Dublin, he had a meeting with Peel, the Prime Minister, and James Graham, the Home Secretary, during which he developed his suspicions concerning Ireland. Contrary to all normal practice, he then published that confidential information in the press, to the fury of his ministers. Upbraided by Graham after the first letter was published, he nonetheless persevered and had the second published as well. The event illustrates his determination to pursue his own agenda, against the orders of his political masters if need be. Trevelyan has thus become the villain in nationalist interpretations of the Famine and even as late as in 1979 a folk ballad, The Fields of Athenry, could still be written about the story of a man convicted during the Great Famine for 'stealing Trevelyan's corn'. ${ }^{18}$

\section{Early histories}

Other, more scholarly approaches to the Great Famine had been explored, however, as soon as 1874, when Canon John O'Rourke, the parish priest of Maynooth, wrote a detailed account based on numerous interviews, reports and official sources, including Trevelyan's Irish Crisis. He disagreed with many of its

${ }^{15}$ Ibid., p. 239.

16 Tim Pat COOGAN, The Famine Plot: England's Role in Ireland's Greatest Tragedy, Basingstoke: Palgrave Macmillan, 2012, p. 230.

${ }^{17}$ Cecil WOODHAM-SMITH, The Great Hunger: Ireland, 1845-9 [1962], London: Four Square Books, 1965, p. 55.

${ }^{18}$ Written by Pete St John and first recorded by Danny Doyle in 1979, it has become a popular anthem for many Irish sports supporters. 
conclusions, however, and was often quite critical of British policy. For instance, the notorious Gregory clause - an amendment to the Poor Relief (Ireland) Act of 1847 proposed by William Gregory, a Tory MP with an estate in Co. Galway, compelling all people occupying a quarter of an acre of land or more to surrender their plots if they wished to obtain public relief - led to a denunciation in no uncertain words: ' $A$ more complete engine for the slaughter and expatriation of a people was never designed':

The previous clause offered facilities for emigrating to those who would give up their land - the quarter-acre-clause compelled them to give it up, or die of hunger. In the fullness of his generosity $\mathrm{Mr}$. Gregory had, he said, originally intended to insert 'half an acre' in the clause, but, like many well-intentioned men, he was over-ruled: he had, he said, been lately in Ireland, and people there who had more knowledge of the subject than he could lay claim to, told him half an acre was too extensive, so he made it a quarter of an acre. It is not hard to conjecture who his advisers were on this occasion. ${ }^{19}$

Small farmers were indeed forced to abandon all they had, ending up in total destitution. O'Rourke also criticised the paltry sums spent by London to alleviate the effects of the famine in comparison with what it was willing to disburse in time of war. The Spectator, in a review of the book, regretted what it considered 'unfair strokes of partisanship', but agreed that 'Sir Robert Peel's and Lord John Russell's Governments entirely failed, until it was too late, to grasp the magnitude of the calamity which was impending'. ${ }^{20}$ O'Rourke's overall assessment of Government policy, highlighting its lack of 'promptness and decision', may be considered as a nationalist interpretation, yet he rejected the accusation of genocide, emphasising both the scale of the challenge and the reality of relief efforts:

To have met the Potato Famine with anything like complete success, would have been a Herculean task for any government. The total failure of the food of a nation was [...] a fact new in history; such being the case, no machinery existed extensive enough to neutralize its effects, nor was there extant any plan upon which such machinery could be modelled. Great allowance must be therefore made for the shortcomings of the Government, in a crisis so new and so terrible; but after making the most liberal concessions on this head, it must be admitted that Lord John Russell and his colleagues were painfully unequal to the situation. They either could not or would not use all the appliances within their reach, to save the Irish people. Besides the mistakes they made as to the nature of the employment which ought to be given, a chief fault of their's was that they did not take time by the forelock - that they did not act with promptness and decision. Other nations, where famine was far less imminent, were in the markets, and

${ }^{19}$ John O'ROURKE, The History of the Great Irish Famine of 1847 With Notices of Earlier Irish Famines [1874], Dublin: James Duffy, $3^{\text {rd }}$ ed. 1902, p. 331.

${ }^{20}$ The Spectator, No. 2499, 20 May 1876, p. 18. 
had to a great extent made their purchases before our Government, causing food to be scarcer and dearer for us than it needed to be. ${ }^{21}$

There were other attempts at writing histories of the Great Famine in following decades, such as W. P. O'Brien's The Great Famine in Ireland published in $1896 .{ }^{22}$ He was not an historian either, but a Poor Law inspector, and his book relies heavily on Trevelyan's account which he considered essential reading, based as it was on the author's 'official access to the best sources of information' on the subject. ${ }^{23}$ In 1921 , George O'Brien, who later taught economics at University College Dublin, published The Economic History of Ireland from the Union to the Famine. The chapters devoted to the Famine, though largely based on the 1851 Census report and on Trevelyan's Irish Crisis, make some of the same points as O'Rourke. He underlines for instance the excessive optimism of Trevelyan's account, quoting George Poulett Scrope, a geologist turned MP, who had derided it on the grounds that 'a stranger to the real events of the last two years might read through the whole hundred pages without even finding out that during the "Irish Crisis" several hundred thousand souls perished in Ireland of want, through the inefficiency of those "colossal" relief measures. ${ }^{24}$

In 1947, at the time of the centenary, a Vincentian priest, Timothy O'Herlihy, tried to outline new possibilities for further research on the subject. ${ }^{25}$ For instance, he proposed an alternative providentialist interpretation, arguing that the Famineinduced Irish diaspora helped to spread Catholicism in the United States and in Commonwealth countries, and to consolidate it in England and Scotland where it was close to extinction; he also suggested 'comparisons with contemporary food shortages in post-war Europe' to better understand the Great Irish Famine. ${ }^{26}$

\section{Revisionism}

It was only from the mid-1930s onwards that a new generation of Irish historians, led by Theodore William Moody and Robert Dudley Edwards, sought to develop a professional approach to their field. Among their objectives, they aimed at dispelling politically-oriented readings of history in general, and nationalist myths in

\footnotetext{
${ }^{21}$ O'ROURKE, The History of the Great Irish Famine, op. cit., pp. 196-197.

${ }^{22}$ William Patrick O'BRIEN, The Great Famine in Ireland and a Retrospect of the Fifty Years, 1845-95; with a sketch of the present condition and future prospects of the congested districts, London: Downey, 1896.

${ }^{23}$ Mary E. DALY, 'Revisionism and Irish History: The Great Famine', pp. 71-89 in D. George BOYCE and Alan O'DAY (eds), The Making of Irish History: Revisionism and the Revisionist Controversy, London: Routledge, 1996, p. 72.

${ }^{24}$ George O'BRIEN, An Economic History of Ireland from the Union to the Famine, London: Longmans, Green \& Co., 1921, p. 261.

25 Timothy O'HERLIHY, The Famine, 1845-47: A Survey of its Ravages and Causes, Drogheda: Drogheda Independent Co., 1947.

${ }^{26}$ Vincent COMERFORD, 'Grievance, Scourge or Shame? The Complexity of Attitudes to Ireland's Great Famine', pp. 51-74 in Christian NOACK, Lindsay JANSSEN, and Vincent COMERFORD (eds), Holodomor and Gorta Mór: Histories, Memories and Representations of Famine in Ukraine and Ireland, London: Anthem Press, 2012, pp. 58-9.
} 
particular. ${ }^{27}$ Through a dispassionate study of sources, they hoped to establish a value-free history, in contrast to books like Mitchel's The Last Conquest for instance.

The Great Famine, with its inherently controversial Anglo-Irish dimension, did not fit in easily with that revisionist agenda, however, and later historians noted that the journal founded by Moody and Dudley Edwards, Irish Historical Studies, only published five articles on the Famine during its first 50 years. ${ }^{28}$ Yet in 1944, when the Taoiseach, Eamon de Valera - a prominent nationalist leader, brought up on tales of Famine suffering in Bruree, his childhood village -, proposed that a book be published to mark the centenary of the Famine in 1945, Moody and Dudley Edwards were asked to edit it. ${ }^{29}$ Beyond the many favourable reviews it received, the main achievement of the book from a revisionist perspective was that it conveyed 'successfully to the wider reading public' that 'the modern scholarly study of history' was not 'a closed exercise in national self-justification'. ${ }^{30}$ More generally, it may be saluted as the first serious attempt by Irish academia to grapple with the Great Famine. Despite its limits and defects, Cormac Ó Gráda - one of the greatest specialists of the Famine - presents it as 'a pioneering and an enduring work', and it was in fact republished in $1994 .{ }^{31}$ Several chapters remain essential reading for anyone interested in the subject, and that by Roger J. McHugh draws on oral tradition - 'an unusual step at the time $e^{, 32}$ - in order to understand how the Famine was experienced and remembered by ordinary people.

The book has been the object of considerable criticism in recent years, however. The editors have come under attack for their laickadaisical approach to their work, which is seen as indicating their lack of interest in it: some chapters and footnotes were mislaid for instance, which contributed to its late publication, and they did very little writing themselves, Kevin Nowlan being asked to ghostwrite the foreword for them. Their revisionism has also been seen as a manifestation of Anglophilia, rather than as part of a truly value-free approach to Irish history. Colm Tóibín, who had had them as teachers during his student days, has cruelly depicted them as suffering from a postcolonial complex:

It was clear from their bearing, the timbre of their voices and their general interest in source material that their time in British universities had been very important for them, that they were happier reading Hansard than going through lists of the names of people who

27 Theodore William MOODY, 'Irish History and Irish Mythology' [1978], pp. 71-86 in Ciaran BRADY (ed.), Interpreting Irish History: The Debate on Historical Revisionism, Dublin: Irish Academic Press, 1994.

${ }^{28}$ Cormac Ó GRÁDA, Ireland before and after the Famine: Explorations in economic history, 1800-1925, Manchester: Manchester UP, 1988, p. 78.

${ }^{29}$ It was only published in 1956, with T. D. Williams replacing Moody who had resigned in 1946.

${ }^{30}$ COMERFORD, 'Grievance, Scourge or Shame?', op. cit., p. 60.

${ }^{31}$ Cormac Ó GRÁDA, 'Introduction to the New Edition', p. xxiv in DUDLEY EDWARDS and WILLIAMS, The Great Famine, op. cit.

${ }^{32}$ Melissa FEGAN, Literature and the Irish Famine, 1845-1919, Oxford: Oxford UP, 2002, pp. 12-13. 
died on coffin ships. It was equally clear that they would never have edited a book about the Famine had they not been commissioned to do so. ${ }^{33}$

Joseph Lee, who is more appreciative of their contribution to the standards of Irish historical writing, reminds his readers that at the time 'external examiners in all Irish universities came from England' and that Irish historians therefore 'tended to internalise the assumptions of English historiography'. ${ }^{34}$ Among those assumptions, there were the 'wild flights of exotic Celtic fancy', especially when it came to the supposed number of victims of British rule in Ireland. To counter that image, they would have naturally presented work of great 'sobriety'. But Lee also acknowledges the inadequacies of the book, in particular the lack of any chapter on population. As to Ó Gráda, he has underlined its excessive focus on the administrative aspects of the Famine with the resulting risk of a 'dehydrated history', of which Dudley Edwards was quite aware. ${ }^{35}$ More generally, The Great Famine downplayed the responsibility of the British government, stressing the conditions that gave rise to an inevitable famine and concluding somewhat lamely on the issue of culpability:

if modern research cannot substantiate the traditional [interpretation] in all its forms, something surely more sobering emerges which is, perhaps, of greater value towards an appreciation of the problems that beset all mankind, both the governors and the governed in every generation. If man, the prisoner of time, acts in conformity with the conventions of society into which he is born, it is difficult to judge him with an irrevocable harshness. So it is with the men of the famine era. Human limitations and timidity dominate the story of the Great Famine, but of great and deliberately imposed evil in high positions of responsibility there is little evidence. The really great evil lay in the totality of that social order which made such a famine possible and which could tolerate, to the extent it did, the suffering and hardship caused by the failure of the potato crop. ${ }^{36}$

Another reason why The Great Famine has sometimes been criticised is linked to Dudley Edwards' patronising attitude towards Cecil Woodham-Smith, an amateur British historian who wrote The Great Hunger shortly after, in 1962. Her account of the Great Famine puts much of the blame for the catastrophe on Trevelyan and generally underscores the responsibility of the British government, notably after Peel left office:

Adherence to laissez-faire was carried to such a length that in the midst of one of the major famines of history, the government was

${ }^{33}$ Colm TÓIBÍN, 'The Irish Famine' [2001], pp. 1-36 in Colm TÓIBÍN and Diarmaid FERRITER, The Irish Famine: A documentary, London: Profile Books, 2004, p. 9.

${ }^{34}$ Joseph LEE, 'The Famine as history', pp. 159-175 in Cormac Ó GRÁDA (ed.), Famine 150: Commemorative Lecture Series, Dublin: Teagasc / UCD, 1997, p. 165.

${ }^{35}$ Cormac Ó GRÁDA, 'Making History in Ireland in the 1940s and 1950s: The Saga of the Great Famine', pp. 269-287 in BRADY, Interpreting Irish History, op. cit., p. 285.

${ }^{36}$ DUDLEY EDWARDS and WILLIAMS, The Great Famine, op. cit., pp. xiv-xv. 
perpetually nervous of being too good to Ireland and of corrupting the Irish people by kindness, and so stifling the virtues of self-reliance and industry. In addition hearts were hardened by the antagonism then felt by the English towards the Irish, an antagonism rooted far back in religious and political history, and at the period of the famine irritation had been added as well. ${ }^{37}$

From this perspective, it may be considered as more nationalist than The Great Famine, although Woodham-Smith was careful to explicitly reject any accusation of genocide. Critical reception in Ireland was initially lukewarm, as academic historians deplored its lack of detachment and its excessive focus on narrative rather than analysis. F. S. L. Lyons, then a senior lecturer in history at Trinity College Dublin, stated that he came out of it with a 'sense of dissatisfaction' because it lacked 'depth' and 'humility', the hallmarks of 'the true historian' ${ }^{38}$ In 1963, history students at University College Dublin, where Dudley Edwards was based, were famously invited to write an essay on the theme: 'The Great Hunger is a great novel'. ${ }^{39}$ It was nonetheless based on a number of archival sources that had been neglected until then, like Trevelyan's papers, and it turned out to be the 'most widely read Irish history book of all time' ${ }^{40}$ It has had a lasting influence on many scholars and it remains a useful book to this day. ${ }^{41}$

Over the following three decades, few works dealing specifically with the Great Famine were published in Ireland. Mary Daly's The Famine in Ireland was one of the exceptions; although a textbook aimed primarily at students, it provided a comprehensive account of the Famine's economic context and outlined possibilities for further research. Yet it came under attack by some for its excessively detached tone and for the fact that it seemed to bend over backwards to protect the British Government's record: 'it remains difficult to conclusively argue that greater sympathy with the Irish case would automatically have guaranteed a dramatically reduced mortality'. ${ }^{42}$ In the same way, Theo Hoppen, while conceding that the government's response during the Famine had been 'extremely inefficient, grudging, and limited', raised the question whether any democratic state could have 'achieved a great deal more ${ }^{43}$ He also emphasised the numerous obstacles to relief, such as the lack of a developed retailing and distribution network, and considered it unlikely that a Dublin-based government could have done much better. As to Roy Foster, he considered that the status of the Famine had been exaggerated, and that if there was indeed a 'watershed in nineteenth-century Irish social and economic history,' it was

${ }^{37}$ WOODHAM-SMITH, The Great Hunger, op. cit., p. 408.

${ }^{38}$ Francis Stuart Leland LYONS, 'The Great Hunger: Ireland by Cecil Woodham-Smith', Irish Historical Studies, Vol. 14, No. 53, March 1964, pp. 77-79.

${ }^{39}$ Cormac Ó GRADA, The Great Irish Famine, London: Macmillan, 1989, p. 11.

40 James S. DONNELLY, Jr., 'The Great Famine: its interpreters, old and new', p. 28, History Ireland, Vol. 1, No. 3, Autumn 1993, pp. 27-33.

${ }^{41}$ Christine KINEALY, "The Historian is a Haunted Man": Cecil Woodham-Smith and The Great Hunger', New Hibernia Review, Vol. 12, No. 4, Winter 2008, pp. 134-143.

${ }^{42}$ Mary E. DALY, The Famine in Ireland, Dundalk: Dungannon Press for the Irish Historical Association, 1986, p. 114.

${ }^{43}$ Karl Theodore HOPPEN, Ireland since 1800: Conflict and Conformity [1989], London: Longman, $2^{\text {nd }}$ ed. 1998 , p. 57. 
'not 1846 but 1815, with the agricultural disruption following the end of the French wars. ${ }^{, 44}$

\section{The great silence}

In 1981, a book assessing recent Irish historiography contained only a handful of references to the Great Famine, thus underlining the dearth of significant research into the Great Famine before that date. ${ }^{45}$ How can this avoidance of the subject be explained, given that the Famine was one of the major events of $19^{\text {th }}$-century Ireland, with long-lasting impact on Irish society? The Irish are famous for their interest in - some might say their obsession with - their own history, but in this case they long avoided coming to terms with the Great Famine. Several reasons have been proposed. There may be a shame linked to famine memories, as suggested among others by John Killen:

The trauma of the famine decade struck a deep blow to the psyche of the Irish people then and in ensuing generations. Anger, hatred, fear and compassion have mixed with shame to produce a reluctance, possibly an inability, to address the enormity of that national tragedy. It is possible that only now, in the last years of the century and of the millennium have the people of Ireland the self-confidence to seek to understand fully the causes, progress and consequences of the famine decade. ${ }^{46}$

Indeed, many famine survivors would have reluctant to admit that they had worked on public works, or begged for food, or spent months in a workhouse - 'all actions that in post-famine Ireland might have detracted from their standing in the community or from the way in which they wished their status to be perceived'. ${ }^{47}$ As to relatives of people dead of hunger, the shame would have been at least as strong, to the point that such cases may well have been underreported, much like suicides today. Faced with utter destitution, many families bolted their doors and lay down to die within their cabins, while others crawled into the corner of a graveyard to die on consecrated ground. The feelings of insecurity attached to such memories would hardly have encouraged further inquiries. Families were forced to decide who would eat and who would not; some abandoned their children in workhouses and emigrated, hoping to be able to send money for the children's fare later. Those who survived would have felt almost unbearable guilt, leading to 'famine denial' ${ }^{48}$ In some cases, hunger may have pushed individuals to extremes like cannibalism, a

${ }^{44}$ Roy F. FOSTER, Modern Ireland, 1600-1972 [1988], Harmondsworth: Penguin, 1989, p. 318

45 Joseph LEE (ed.), Irish Historiography, 1970-9, Cork: Cork UP, 1981.

46 John KILLEN, 'Introduction', p. 9 in John KILLEN (ed.), The Famine Decade: Contemporary Accounts, 1841-1851, Belfast: Blackstaff, 1995, pp. 1-9.

${ }^{47}$ James S. DONNELLY, Jr., The Great Irish Potato Famine [2001], Stroud: The History Press, $4^{\text {th }}$ ed. 2010 , p. 38.

48 Donnchadh Ó CORRÁIN, 'The Great Famine, 1845-9', pp. 58-84 in Donnchadh Ó CORRÁIN and Tomás O'RIORDAN (eds), Ireland 1815-1870: Emancipation, Famine and Religion, Dublin: Four Courts Press, 2011, p. 71. 
taboo that would have also contributed to a collective amnesia or at the very least an unwillingness to confront the past. ${ }^{49}$

In the same way, some aspects of the Famine were awkward insofar as they challenged the dominant nationalist narrative of Protestant landlords pitted against Catholic tenants, or of British ministers determined to decimate the Irish. There were in fact several dimensions to the struggle for land prevalent in Ireland at the time, and if those which conformed to the nationalist interpretation were given pride of place, those involving struggles among Catholic Irishmen - between agricultural labourers and strong farmers for instance - were so problematic that 'the only safe course was amnesia', as Joseph Lee has indicated. ${ }^{50}$ A number of merchants and traders also made profits at the time, notably those who lent money at usurious rates of interest. There is a tension therefore between the dominant nationalist discourse and the fact that a number of Catholics benefited from the situation. Colm Tóibín has underlined the fact that in the aftermath of the Famine, divisions within the 'Irish nation' - especially class divisions - were passed under silence, while blame was focused on the English and the Ascendancy.

Such a reaction may be quite natural, yet the underlying trauma remains, notably in the western parts of the island which suffered the most and where some people 'claim to be haunted still by the silences and absences and emptiness that the Famine left' ${ }^{51}$ If that statement seems to stretch the limits of credulity, a statement by the Taoiseach in May 2014 during the National Famine Commemoration may be worth reporting. Speaking in Strokestown, Co. Roscommon, which lost $60 \%$ of its population during the Famine through death and emigration, Enda Kenny referred to the strength of Famine atavisms today:

As their descendants, we carry the generational memory of An Gorta Mor, deep within us. It's in how we stop momentarily when we hear summer blight warnings on the radio; it's in the coldness in the back of the neck at the particular smell of a bag of potatoes that has spent too long in the cupboard. ${ }^{52}$

Kenny, who was himself born in Co. Mayo, in the West, may have been expressing an important fact concerning the impact of the Famine on the Irish psyche, which would have contributed to a reluctance to dwell on the event.

Another factor that must be taken into account is the context in Northern Ireland. During the conflict (1968-1998), most Irish historians became wary of providing any academic legitimacy to the IRA, which was then waging a deadly campaign against the Union on the basis of a colonial narrative of Anglo-Irish history. There is a fairly clear correlation between the Northern Irish conflict and the

${ }^{49}$ Cormac Ó GRÁDA, 'Eating people is wrong: famine’s darkest secret?' (31 January 2013). Available at $<$ http://ssrn.com/abstract $=2209806>$.

${ }^{50}$ Joseph LEE, 'The Land War', pp. 106-116 in Liam DE PAOR (ed.), Milestones in Irish History, Cork: Mercier Press, 1986, p. 106.

${ }^{51}$ TÓIBÍN, 'The Irish Famine', op. cit., p. 9.

${ }^{52}$ Quoted in the Irish Independent, 12 May 2014. 
rise of revisionism in the 1970s: while republicans endorsed Mitchel's view of the Famine as a genocide, most historians sought to distance themselves from that position. Mary Daly admitted for instance in 1995 having downplayed the level of mortality as well as the responsibility of the British Government during the Great Famine because of her unwillingness to seem to support the republican agenda. ${ }^{53}$

\section{The sesquicentenary}

The importance of that factor seems to be confirmed by the coincidence of the first IRA ceasefire in 1994 and the $150^{\text {th }}$ anniversary of the Famine in 1995, which resulted in an outpouring of books on the subject. The sesquicentenary thus combined with new hopes for peace in Northern Ireland, which allowed historians to study the Famine with greater intellectual freedom than before: the "parity of esteem' enshrined in the peace process could also apply to diverging historical schools. In addition, historians wrote in a context that was transformed by a thawing in Anglo-Irish relations after Tony Blair became Prime Minister. Determined to secure a lasting peace settlement in Northern Ireland, he communicated a statement on 31 May 1997 through the British ambassador in Dublin, which was read on the following day by Gabriel Byrne, a famous Irish actor, at a Great Famine commemoration in Millstreet, Co. Cork -

The Famine was a defining event in the history of Ireland and of Britain. It has left deep scars. That one million people should have died in what was then part of the richest and most powerful nation in the world is something that still causes pain as we reflect on it today. Those who governed in London at the time failed their people through standing by while a crop failure turned into a massive tragedy. We must not forget such as dreadful event. ${ }^{54}$

This official apology allowed Irish historians to look at Britain's role in the Famine without any pressure to minimise its responsibility in order to avoid the charge of Anglophobia. ${ }^{55}$ Scholars from other countries or other fields, who were less constrained by such considerations, had already made significant contributions to the understanding of the Great Famine. Joel Mokyr, an American economic historian, published an important book in 1983, Why Ireland Starved, which proposed a novel approach based on econometric methods. Among his sometimes controversial conclusions, he refuted claims that Ireland was overpopulated prior to the Famine; as to his assessment of British policy, it seemed to bolster the nationalist case:

53 Christine KINEALY, The Great Irish Famine: impact, ideology, and rebellion, Basingstoke: Palgrave Macmillan, 2002, p. 4.

${ }^{54}$ Jason A. EDWARDS and Amber LUCKIE, 'British Prime Minister Tony Blair's Irish Potato Famine Apology', Journal of Conflictology, Vol. 5, Issue 1, 2014, pp. 43-51.

${ }_{55}$ Alvin JACKSON, 'Irish History in the Twentieth and Twenty-First Centuries', pp. 3-21 in Alvin JACKSON (ed.), The Oxford Handbook to Modern Irish History, Oxford: Oxford UP, 2014, p. 8 . 
Most serious of all, when the chips were down in the frightful summer of 1847, the British simply abandoned the Irish and let them perish. There is no doubt that Britain could have saved Ireland. The British treasury spent a total of about $£ 9.5$ million on famine relief. [...] A few years after the famine, the British government spent $£ 69.3$ million on an utterly futile adventure in the Crimea. Half that sum spent in Ireland in the critical years 1846-9 would have saved hundreds of thousands of lives. [...] It is not unreasonable to surmise that had anything like the famine occurred in England or Wales, the British government would have overcome its theoretical scruples and would have come to the rescue of the starving at a much larger scale. Ireland was not considered part of the British community. ${ }^{56}$

Another academic based in the United States, James S. Donnelly, Jr., contributed several chapters in the New History of Ireland volume devoted to the 1801-70 period, highlighting among others the limits of British relief policy. ${ }^{57}$ As to Cormac Ó Gráda, his background in economics allowed him to approach the Famine from an angle different to that of other historians, and his abundant and wideranging work since the late 1980s has played a major role in renewing Famine research. He has contributed decisively to the 'emergence, from the mid-1990s onwards, of a new generation of famine interpretation that is post-revisionist while continuing to challenge the excesses and simplifications of earlier nationalistic interpretations'. 58

It is hardly possible to sum up all the new paths for research opened by postrevisionists here, but a few points may be outlined. ${ }^{59}$ For instance, the conventional wisdom according to which Irish agriculture was characterised by its backwardness has been challenged by several historians. Some have underlined the major developments that occurred between the late $18^{\text {th }}$ century and the $1840 \mathrm{~s}$, which indicate that Ireland adapted itself quickly to new circumstances, in accordance with the specific nature of its geography and the constitutional framework of the Union. ${ }^{60}$ The fact that Ireland was able simultaneously to feed a rapidly expanding population and to increase its agricultural exports to Britain during the first half of the $19^{\text {th }}$ century reflects a performance which should not be minimised - according to Ó Gráda, Irish agricultural production 'presumably doubled' between 1800 and 1845, no mean feat. ${ }^{61}$ As to David Lloyd, he has argued that British norms of modernity

56 Joel MOKYR, Why Ireland starved: a quantitative and analytical history of the Irish economy, 1800-1850 [1983], London: Allen \& Unwin, rev. ed. 1985, pp. 291-2.

${ }^{57}$ VAUGHAN, Ireland under the Union, op. cit. Those chapters are included in his book The Great Irish Potato Famine, op. cit.

${ }^{58}$ Margaret KELLEHER, 'The Irish Famine: History and Representation', pp. 84-99 in Mary MCAULIFFE, Katherine O'DONNELL and Leeann LANE (eds), Palgrave Advances in Irish History, Basingstoke: Palgrave Macmillan, 2009, p. 90.

${ }^{59}$ For a broader view of recent research, see for instance Christine KINEALY's introduction to the new edition of her book This Great Calamity: The Irish Famine 1845-52 [1994], Dublin: Gill \& Macmillan, 2006, pp. xxxiii-xl.

60 Kevin WHELAN, 'Pre and Post-Famine Landscape Change', pp. 19-33 in Cathal PÓIRTÉIR (ed.), The Great Irish Famine, Cork: Mercier / RTE, 1995.

${ }^{61}$ Ó GRÁDA, Ireland before and after the Famine, op. cit., pp. 57-58. 
have led to a misunderstanding of Irish realities: the communal or 'rundale' system of farming was perfectly suited to the poorer lands of the West, as well as helping to maintain a strong cultural life within small clusters of houses known as clachans. ${ }^{62}$

Ó Gráda has shown that Ireland was changing prior to the Famine, notably from a demographic point of view, and that, had the blight occurred a couple of decades later, it could well have escaped its catastrophic effects. In other words the Great Famine was not an inevitable event due to a Malthusian dead-end in which Irish society was allegedly stuck, but an external shock of great magnitude which could not be foreseen. ${ }^{63}$ Ó Gráda has engaged in comparative work as well, establishing that the Great Famine was probably the deadliest of all famines in recorded history proportionally to the population - with the possible exception of the insufficiently documented 1740-41 Irish famine -, and has built on the theories of Nobel Prize laureate Amartya Sen, whose work on famines in India and Bengal suggests that famines are due less to shortages of food than to issues of entitlement to existing stocks.

Peter Gray has studied in great detail the ideological background against which British ministers and officials devised policies for Ireland, concluding that laissezfaire, providentialism and moralism were three major concepts which guided their reactions to the Famine. ${ }^{64}$ The influence of the Manchester school of economics, which was considerable at the time, militated against State intervention in the economy. It was linked to some extent to providentialism, the doctrine that human affairs are regulated by divine agency for human good, in the sense that the workings of the market were seen as reflecting the judgement of God. This in turn was connected to moralism, the idea that the root of Ireland's problems was to be found in the people's improvidence, irresponsibility and laziness.

Yet providentialism was a protean concept with many nuances and degrees. Ministers and officials - as well as the Irish - agreed on the whole that the Famine was a 'visitation by God', though their interpretations varied considerably. For Peel and Graham, it required decisive action on the part of the government; for Wood, Senior and Trevelyan, it was an opportunity to end Ireland's misery by transforming its social and economic structures. ${ }^{65}$ As to the Irish, many saw it as a punishment for their sins, while Daniel O'Connell saw it as a test of charity within the British Isles.

Donal Kerr has focused on the role of the Churches, in particular that of the Catholic Church. ${ }^{66}$ In 1847 O'Connell supported Lord John Russell because of the 'justice for Ireland' policy he had led in previous years, yet the Whig administration

${ }^{62}$ David LLOYD, 'The Indigent Sublime: Spectres of Irish Hunger', Representations, Vol. 92, No. 1, Fall 2005, pp. 152-185.

${ }^{63}$ Cormac Ó GRÁDA, Black '47 and Beyond: The Great Irish Famine in History, Economy, and Memory, Princeton: Princeton UP, 1999.

${ }^{64}$ GRAY, Famine, Land and Politics, op. cit.

${ }^{65}$ Robin HAINES, in her revisionist biography of the Assistant Secretary (Charles Trevelyan and the Great Irish Famine, Dublin: Four Courts Press, 2004), has argued that he was not an evangelical providentialist and that his influence has been overstated.

${ }^{66}$ Donal A. KERR, 'A Nation of Beggars'? Priests, People, and Politics in Famine Ireland, 1846-1852 [1994], Oxford: Oxford UP, 1998. 
failed to achieve its ambition to assimilate Ireland within the United Kingdom, partly because of the religious divide between Ireland and Great Britain. Evictions and growing violence - notably the murder of Major Denis Mahon in November 1847 - led to denunciations of the Catholic clergy in the British press, ${ }^{67}$ and a number of priests in turn joined the Young Ireland movement. At the same time, several Protestant organisations sought to use the Famine to convert Irish Catholics in exchange for food, thus fuelling religious tensions. As to the Vatican's decision to re-establish an episcopal hierarchy in Britain in 1850, it provoked a wave of antiCatholic hysteria, with Westminster passing the 1851 Ecclesiastical Titles Bill in retaliation.

Christine Kinealy has focused among others on the issue of food exports. Most historians agree that Ireland imported more food than it exported after 1847 and that a ban on exports might thus have been counterproductive, without mentioning its political difficulties, grain producers and merchants being a powerful lobby. Austin Bourke for instance studied official trade figures for grain and concluded that the retention of home-grown food could have served 'only as a temporary device to win time'. ${ }^{68}$ But Kinealy has underlined that those official statistics are not entirely reliable, that one must also take into account other agricultural exports - dairy products, livestock, etc. -, and that even a limited amount of food would have made all the difference in the world for many hungry people at a crucial moment during the Famine. ${ }^{69}$

\section{Conclusion}

In 1996, while assessing the state of research on the Great Famine, Mary Daly concluded by calling for a new approach, characterised by 'a blend of analysis and emotion' in order to 'meet the needs of scholarship and popular memory alike ${ }^{70}$ - in other words, an approach reconciling the empathy of nationalist narratives and the detachment of scholarly history or, if one wishes, overcoming both the administrative aridity of Charles Trevelyan and the passionate outrage of John Mitchel. Two writers may well have come close to fitting that exacting description. Ciaran Ó Murchadha has combined scholarly research and first-hand accounts in his book, Ireland's Agony, thus achieving a valuable balance between historical analysis and the human interest angle. ${ }^{71}$ As to Enda Delaney, he has also proposed an innovative book, The Curse of Reason, in which the lives of four actors of the Famine are intertwined, thus offering a multifaceted view of the event: in addition to

${ }^{67}$ According to Peter DUFFY (The Killing of Major Denis Mahon: A Mystery of Old Ireland, New York: Harper, 2007), there is no clear evidence, despite contrary allegations in the press, that the parish priest incited his flock to kill the landlord who had evicted thousands of his tenants, many of whom died during the crossing of the Atlantic on a coffin-ship which he had paid for.

68 Patrick Martin Austin BOURKE, 'The Irish Grain Trade, 1839-48', Irish Historical Studies, Vol. 20, No. 78, Sept. 1976, pp. 156-169.

${ }^{69}$ For a summary of the debate, see Christine KINEALY, 'Food exports from Ireland, 184647', History Ireland, Vol. 5, No. 1, Spring 1997, pp. 32-36.

${ }^{70}$ DALY, 'Revisionism and Irish History, op. cit., p. 86.

${ }^{71}$ Ciaran Ó MURCHADHA, The Great Famine: Ireland's Agony 1845-1852, London: Continuum, 2011. 
many secondary sources, he builds on the contemporary writings of Trevelyan, Mitchel, Elizabeth Smith - the wife of a Protestant landlord, who held a detailed diary - and John McHale, the combative nationalist Archbishop of Tuam, to depict Ireland in all of its complexity during the Famine. ${ }^{72}$

If studies of the Great Famine were all too scarce before the 1990s, partly because of unresolved issues linked to generational memories of the catastrophe and of the conflictual legacy of Anglo-Irish relations, ${ }^{73}$ they have become very abundant, diverse and wide-ranging since then, offering many new perspectives. They have been accompanied by official commemorations, reflecting growing public interest in the Famine in recent years. Since 2008 for instance, an annual National Famine Memorial Day is organised under the auspices of the Government, with a parallel event held abroad to emphasise the links with the Irish diaspora. ${ }^{74}$ Indeed, if the Famine is essential to an understanding of Irish history - and from that point of view one can only salute the great vitality of Famine studies in recent years -, it also constitutes a significant aspect of the history of several English-speaking countries in the world.

72 Enda DELANEY, The Curse of Reason: The Great Irish Famine, Dublin: Gill \& Macmillan, 2012.

${ }^{73}$ Tom HAYDEN (ed.), Irish Hunger: Personal Reflections on the Legacy of the Famine, Boulder, CO: Robert Rineharts Publishers, 1997.

${ }^{74}<$ www.irishfamine.ie $>$ 